\title{
PELATIHAN MERAJUT BERBASIS ONLINE MASYARAKAT KAYEN KIDUL
}

\author{
Karisma Cindy Selianawati ${ }^{\star}$ Latifatun Nisa, Putri Siti Hajar, Raudhatul Jannah \\ karismacindys@gmail.com \\ Prodi Pendidikan IPS, Fakultas IImu Sosial, Universitas Negeri Malang \\ Diterima 29 November 2020, dipublikasikan 30 April 2021
}

\begin{abstract}
Abstrak
Pandemi yang semakin memperburuk keadaan ekonomi menjadikan masyarakat harus bisa mengandalkan potensi yang mereka miliki agar bisa mendapat penghasilan dengan bekerja dirumah saja. Hal tersebut menjadikan latar belakang dari kegiatan merajut yang dilakukan oleh masyarakat di Kayen Kidul. Tujuan dan hasil dari kegiatan merajut ini selain mendapatkan penghasilan dan bisa memanfaatkan media elektronik dengan maksimal karena berjualan online. Metode yang digunakan adalah kualitatif deskripsi dengan sumber dari data primer dan sekunder.
\end{abstract}

Kata Kunci: Pemberdayaan Masyarakat, Komunitas Rajut, Pelatihan Online

\section{PENDAHULUAN}

Pada dasarnya setiap orang berhak mendapatkan sebuah pekerjaan untuk memenuhi kebutuhan sandang pangan bagi dirinya dan keluarga. Pekerjaan didapatkan melalui usaha. Perlu diketahui kondisi keadaan ekonomi saat ini sedang tidak stabil disebabkan oleh pandemi. Pandemi membuat berbagai bidang mengalami penurunan khususnya dibidang ekonomi. Masalah ekonomi makro berujung pada pengangguran. Angka pengangguran di Indonesia terhitung dalam setahun terakhir bertambah menjadi 60 ribu orang (Badan Pusat Statistik, 2020). Pengangguran dalam jumlah tinggi membuat siklus ekonomi terganggu baik siklus ekonomi negara hingga ekonomi global.

Pengangguran merupakan jumlah tenaga kerja dalam perekonomian yang secara aktif mencari pekerjaan tetapi belum menemukannya. Pengangguran menyebabkan ketidakseimbangan antara pendapatan dan pengeluaran. Pengangguran disebabkan oleh banyak faktor, salah satunya adalah pemutusan hubungan kerja dengan perusahaan (PHK). Pemutusan hubungan kerja dilakukan karena keadaan sebuah perusahaan tidak stabil sehingga perusahan akan membuat sebuah kebijakan. Tenaga kerja karyawan yang dulunya produktif berubah menjadi pasif, sehingga harus mencari lapangan kerja kembali walau lapangan kerja sangat minim. Wilayah perkotaan industri menjadi daerah yang terdampak pengangguran sekaligus pusat pemutusan hubungan pekerjaan paling tinggi.

Kota kediri kota yang memiliki perusahaan industri sebuah pabrik khususnya pada daerah Kayen Kidul. Banyak masyarakat Kayen Kidul yang terkena pemutusan hubungan kerja (PHK) dengan pabrik. Kesejahteraan hidup menurun akibat penurunan kebutuhan sandang pangan yang tidak mencukupi. Kebutuhan sandang pangan seharusnya tetap terpenuhi untuk menjaga kualitas kesehatan yang dibutuhkan. Demi menjaga siklus ekonomi tetap stabil maka dibutuhkan ide untuk menjadikan sebuah solusi. Kemampuan yang sudah dimiliki masyarakat Kayen Kidul bisa menjadi potensi melalui kelompok kerja kreatif. Potensi kemampuan masyarakat Kayen Kidul dapat diasah melalui ketrampilan rajut. Seperti yang terdapat dalam penelitian Kartikowati, S., Gimin, Sumarno, \& Trisnawati, F.(2013), dari kegiatan merajut yang dilakukan seorang ibu rumah tangga akan tetap bisa mendapatkan penghasilan dengan potensi dalam membuat suatu produk merajut yang memiliki nilai jual. Mereka bisa memanfaatkan waktu mereka dengan kegiatan yang produktif yang bisa menciptakan peluang usaha. Sedangkan kegiatan merajut di daerah Kayen Kidul ini juga memberikan beberapa manfaat yaitu salah satunya dapat meningkatkan pendapatan masyarakat terutama di masa pandemi.

\section{METODE}


Kegiatan pengabdian masyarakat ini dalam membahas permasalahan yang telah diangkat menjadi latar belakang pelaksanaan kegiatan menggunakan pendekatan metode berbasis pelatihan online. Melalui rancangan kegiatan pengabdian yang akan digunakan dalam proses kegiatan ini dimulai dengan mencari target sasaran pelatihan yang dikumpulkan dan dimasukkan ke dalam dalam grup WA yang merupakan media pelatihan online. Pelatihan yang diberikan adalah ketrampilan rajut yang difokuskan selama dua minggu sekali dan sekaligus menjadi evaluasi akhir. Dalam pelatihan ketrampilan rajut, alat dan bahan yang digunakan adalah benang rajut, hakpen atau jarum rajut, dan dakron. Setelah dilakukan evaluasi akhir atas produk rajutan yang dihasilkan kemudian dilakukan penentuan harga produk berdasarkan kualitas rajutan tersebut.

Target sasaran yang diambil sebagai subjek pengabdian meliputi masyarakat sekitar Desa Kayen Kidul yang terkena PHK. Hal ini sesuai dengan fokus utama pelaksanaan kegiatan ini untuk meminimalisir jumlah pengangguran disebabkan adanya PHK tersebut. Masyarakat yang telah dikumpulkan inilah yang diberikan pelatihan rajut online melalui media grup WA.

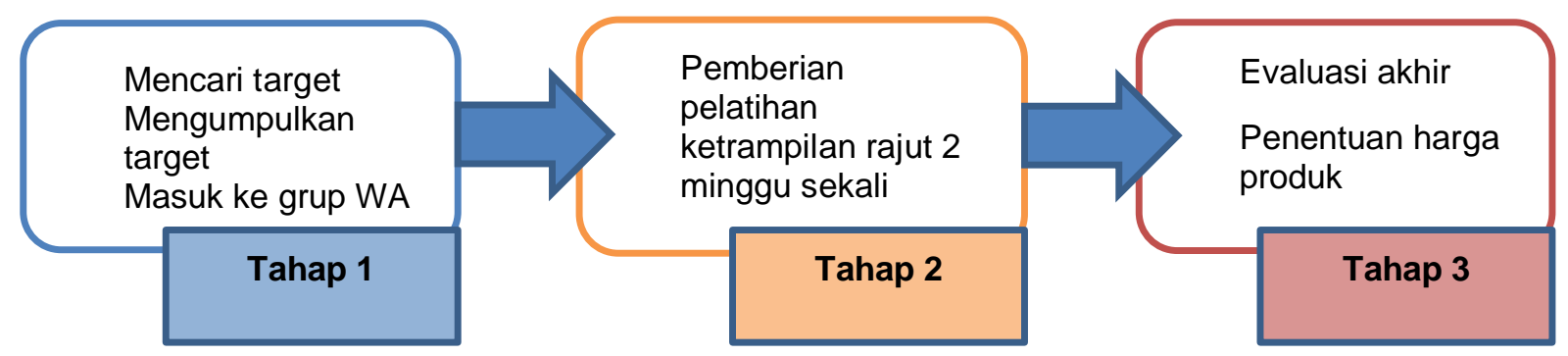

Bagan 1. Tahapan Pelaksanaan Kegiatan

Pengambilan data sekaligus digunakan sebagai pengembangan instrumen kegiatan dengan sumber data yang dikumpulkan melalui data primer dan sekunder. Data yang dikumpulkan berupa data primer terdiri dari serangkaian kegiatan yang dilaksanakan dan data sekunder terdiri dari data-data pendukung seperti kepustakaan dan kegiatan sejenis lainnya. Analisis data yg digunakan yaitu teknik metode analisis kualitatif. Penelitian kualitatif bertujuan untuk memberikan pengalaman empiris dengan menangkap makna yang muncul di bidang penelitian yang sedang dikaji yaitu dengan interaksi secara langsung peneliti dan objek yang akan diteliti (Pendit, 2003). Pada kegiatan ini metode analisis kualitatif digunakan untuk memahami masalah sosial pada pelatihan keterampilan merajut berbasis online berdasarkan pada penciptaan gambaran holistic lengkap langsung dari pengalaman lapangan pelaksanaan kegiatan kemudian dibentuk dalam bentuk teks, laporan secara rinci yang dilihat dari penyedia informasi, dan tersusun secara alami dalam bentuk laporan kegiatan.

\section{HASIL DAN PEMBAHASAN}

\section{Pemberdayaan Masyarakat}

Pemberdayaan masyarakat merupakan kalimat yang berasal dari kata "daya" (power). Sedangkan pemberdayaan berasal dari kata "epower" yang memiliki dua arti. Pengertian pertama yaitu "to give power or authority" yang memiliki arti memberikan suatu kekuasaan, mengalihkan suatu kekuasaan atau mendelegasikan suatu otoritas ke pihak lain. Pengertian kedua adalah "to give ability or to enable" yang memiliki arti sebagai usaha untuk memberikan kemampuan. (sari, 2016). Pemberdayaan masyarakat bertujuan mengembangkan kemampuan seseorang untuk memenuhi kebutuhan dasar, meningkatkan pendapatan, dan memperoleh barang dan jasa yang diperlukan.

Pemberdayaan masyarakat harus terus dilakukan hingga tercapai keseimbangan antara pemerintah dan masyarakat. Oleh karena itu, pemberdayaan dalam kehidupan nyata sangat diperlukan untuk keberlangsungan kehidupan masyarakat. (Desiati, 2013). Komunitas rajut merupakan salah satu kegiatan pemberdayaan masyarakat untuk meningkatkan pendapatan ekonomi masyarakat, khususnya pada masa pandemi di wilayah Kayen Kidul.

\section{Potensi Pengembangan}


Potensi yang dimaksud disini yaitu sumber kekuatan, kemampuan, serta kemauan menyanggupi akan sesuatu hal untuk dikembangkan, dengan konsep dapat meningkatkan kesejahteraan masyarakat (Depdikbud, 1989). Secara umum pengembangan potensi mempunyai tujuan mendorong tercapainya kedisiplinan dan keberanian masyarakat dengan cara mengembangkan potensi terbaik dan menguatkan kelembagaan, serta pemberdayaan masyarakat. Dalam mengembangkan potensi perlu adanya partisipasi keikutsertaan masyarakat agar nantinya mereka bisa mempunyai tanggung jawab. Langkah tersebut harus diperhatikan agar nantinya proses pelaksanaan ini bisa terwujud dan berjalan secara efektif sesuai dengan kondisi potensi yang dimiliki masyarakat.

Potensi kemampuan masyarakat di Kecamatan Kayen Kidul Kota Kediri diasah melalui ketrampilan rajut. Ketrampilan rajut dipilih karena mudah dipahami, dengan harga yang terjangkau, serta bahan dasar yang mudah ditemukan. Ketrampilan rajut menghasilkan sebuah karya seperti taplak meja, tas, tempat pensil, boneka, dan lain-lain. Karya tersebut dapat dijual sehingga masyarakat mendapatkan pemasukan. Setelah masyarakat mendapatkan pemasukan, pengembangan kelompok kerja dapat dilakukan, kelompok kerja pun akan terus berkembang dan maju lapangan kerja terbentuk. $\mathrm{Hal}$ ini berdampak positif dengan tujuan menstabilkan ekonomi global dan masalah pengangguran dapat teratasi.

\section{Pemanfaatan Media Elektronik}

Di era industri 4.0 hubungan manusia dengan teknologi begitu dekat. Berkembang pesatnya teknologi dan ilmu pengetahuan pada saat ini dapat memudahkan kegiatan manusia di bidang apapun. Tidak hanya memudahkan segala aktivitas namun juga dipergunakan agar manusia bisa mendapatkan informasi dari berbagai sumber yang benar dan akurat. Sehingga segala aktivitas manusia bisa mengikutsertakan media elektronik. Namun tidak benar jika dalam penggunaan media elektronik sampai mengalami kecanduan.

Media elektronik bisa menyebabkan seseorang kecanduan karena pemakai merasa sangat nyaman dengan kemudahan yang telah diberi oleh media elektronik tersebut (Rakhmawati, Ismah, \& Lestari , 2020). Salah satu bentuk dari media elektronik adalah gadget/gawai. Masyarakat era 4.0 sudah tidak lazim dengan kata gadget karena sebagian dari mereka menggunakan gadget sebagai alat untuk mereka bekerja. Masyarakat yang pintar dalam penggunaan gadget pasti akan mendapat banyak manfaat.

Jika pekerjaan sudah melibatkan media elektronik maka dalam sebuah perdagangan terdapat jual beli, penyebaran ataupun pemasaran yang dilakukan dengan penggunaan internet, TV ataupun jaringan komputer yang biasa disebut dengan e-commerce. Bidang ekonomi memang terlihat dominan dalam penggunaan media elektronik. Disetiap kesempatan apapun selalu berusaha mengikutsertakan media elektronik sehingga sangat memudahkan bagi mereka yang masih pemula dalam dunia wirausaha (Kusumadewi \& Fitriani, 2020).

Banyak masyarakat yang pintar dalam menggunakan media elektronik di era modern ini. Namun banyak juga masyarakat yang tidak bisa memanfaatkan bahkan tidak bisa mengakses media elektronik dikarenakan keterjangkauan ekonomi keluarga dan ada pula karena wilayah mereka yang terpelosok (Akhmad, 2015). Tidak sedikit pula masyarakat yang mampu mengakses dan menggunakan media elektronik tetapi tidak bisa memanfaatkan secara maksimal.

Masyarakat yang kurang maksimal dalam pemanfaatan media elektronik biasanya mereka yang memiliki pekerjaan tetap yang ada di desa seperti petani dan buruh pabrik. Masyarakat di Kecamatan Kayen Kidul menjadi target dalam pengabdian masyarakat kali ini lebih spesifiknya adalah mereka yang menganggur atau yang terkena PHK di masa pandemi. Dalam kegiatan pengabdian yang dilakukan adalah pelatihan merajut secara online.

Sudah pasti dalam kegiatan pengabdian kali ini sangat memanfaatkan media elektronik yang mereka miliki seperti HP ataupun laptop. Pelatihan dilakukan dengan membuat grup WhatsApp yang kemudian setiap minggunya diberikan video tutorial dalam merajut. Jika hasil karya sudah selesai akan diberi sebuah info mengenai branding. Dan selanjutnya bisa mereka jual dengan media sosial yang mereka miliki. 


\section{Branding}

Di zaman yang serba canggih pemanfaatan melalui kecanggihan teknologi, khususnya dalam bidang usaha yang lebih dikenal dengan toko online sedang menjadi sebuah trend masa kini. Aktivitas bisnis dengan elektronik dengan sebutan lain yaitu e-business atau e-commerce, dimana telah memberikan kemudahan bagi pihak produsen, penjual maupun dan pembeli sampai pada customers (Grandon \& Pearson 2004).Kecanggihan teknologi membuat potensi jangkauan produk lebih meluas menjadi alasan bagi pengusaha untuk memilih penjualan melalui online. Dampak nya cukup berpengaruh pada penghasilan, terlebih pada masa sekarang banyak orang gemar membeli secara online selain praktis dan efektif, konsumen tidak perlu capek datang ke toko. Sehingga masyarakat kayen kidul yang memilih penjualan secara online. Penjualan melalui online memang berdampak positif pada penghasilan, namun perlu diteliti kembali, bagaimana dampak pemasaran tersebut terhadap produk yang dipasarkan agar produk tidak disalahgunakan oleh orang lain.

Menurut Kotler brand memiliki pengertian sebuah identitas panggilan nama, istilah, tanda, simbol, kerangka rancangan, atau perpaduan kombinasi yang terbentuk oleh semua unsur yang digunakan untuk menjadi identitas ran mengenali produk atau perusahaan jasa dari perseorangan atau dibuat kelompok penjual dengan pengusaha pesaing lainya (Kotler, 2000). Brand menjadi hal yang penting untuk bisnis usaha. Melalui brand produk akan lebih dikenal oleh konsumen. Pemberian branding pada sebuah produk selain membuat konsumen lebih mengerti apa yang ia beli, pemberian branding dapat juga membuat karakteristik dan nilai pada sebuah produk muncul. Konsumen akan langsung mengetahui produk apa itu hanya dengan melihat brand yang dimiliki produk tersebut.

Masyarakat Kayen Kidul yang sedang melakukan pengembangan usaha sangat membutuhkan sebuah branding untuk membedakan nilai dan karakteristik produk yang dimiliki. Terlebih lagi kerajinan tangan rajut merupakan kerajinan yang mudah dalam pengerjaannya. Sehingga pesaing dalam usaha bisnis ini juga banyak. Persaingan yang ketat dengan berbagai macam model kerajinan tangan. Pesaing yang banyak memungkinkan sebuah produk akan diklaim oleh orang lain, agar produk tersebut tidak diklaim orang lain. Branding pada produk harus diperhatikan.

Pemberian branding produk mengikat loyalitas pelanggan yang menuju pada tingkat keberhasilan pemasaran produk (Nastain, 2017). Seperti brand yang diciptakan oleh Honda melambangkan kebudayaan jepang dengan teknologi yang maju. Dari rujukan tersebut maka penamaan dapat disesuaikan dengan citra diri produk serta mempunyai makna. Branding akan mudah dipahami pelanggan jika mempunyai ciri khas. Pelanggan secara tidak langsung akan mempunyai sebuah persepsi terhadap produk. Sehingga pemberian branding harus memperhatikan image yang dibuat dari segi dan tujuan bisnis.

\section{KESIMPULAN}

Pemberdayaan masyarakat ditujukan untuk mengembangkan kemampuan seseorang. Oleh karena itu, mereka mempunyai kemampuan yang dapat memenuhi kebutuhannya. Komunitas rajut adalah salah satu kegiatan pemberdayaan masyarakat yang diharapkan bisa menambah perekonomian masyarakat khususnya di masa pandemi ini yang terjadi di daerah Kayen Kidul. Potensi kemampuan masyarakat di Kecamatan Kayen Kidul Kota Kediri diasah melalui ketrampilan rajut. Ketrampilan rajut menghasilkan sebuah karya seperti taplak meja, tas, tempat pensil, boneka, dan lainlain. Karya tersebut dapat dijual sehingga masyarakat mendapatkan pemasukan. Setelah masyarakat mendapatkan pemasukan, pengembangan kelompok kerja dapat dilakukan, kelompok kerja pun akan terus berkembang dan maju lapangan kerja terbentuk. Hal ini berdampak positif dengan tujuan menstabilkan ekonomi global dan masalah pengangguran dapat teratasi. Pengabdian masyarakat di Kecamatan Kayen Kidul memanfaatkan media elektronik dalam pelaksanaannya. Dengan begitu masyarakat bisa mendapatkan informasi serta relasi dan juga memaksimalkan dalam penggunaan media sosial untuk mencari kesempatan memperbaiki keadaan ekonomi. Masyarakat Kayen Kidul yang sedang melakukan pengembangan usaha sangat membutuhkan sebuah branding untuk membedakan nilai dan karakteristik produk yang dimiliki. Branding akan mudah dipahami pelanggan jika mempunyai ciri khas. Pelanggan secara tidak langsung akan mempunyai sebuah persepsi 
terhadap produk. Sehingga pemberian branding harus memperhatikan image yang dibuat dari segi dan tujuan bisnis.

\section{DAFTAR PUSTAKA}

Akhmad, K. A. 2015. Pemanfaatan Media Sosial bagi Pengembangan Pemasaran UMKM (Studi Deskriptif Kualitatif pada Distro di Kota Surakarta). DutaCom Journal Vol 9 No 1.

Badan Pusat Statistik. 2020. Agustus 2020: Tingkat Pengangguran Terbuka (TPT) sebesar 7,07\%

Depdikbud. 1989. Kamus Besar Bahasa Indonesia. Jakarta: Depdikbud.

Desiati, R. 2013. PEMBERDAYAAN MASYARAKAT MELALUI PENGELOLAAN PROGRAM. Diklus, 253-262.

Grandon and Pearson, 2004 Aktifitas bisnis secara elektronik ini (e business/e- commerce) Kerja IAIN

Sunan Kalijaga Yogyakarta. Aplikasia, Jumal Aplikasi Ilmu-ilmu Agama, Vol. II, No. 2 Desember 2001:197-211

Kartikowati, S., Gimin, Sumarno, \& Trisnawati, F. 2013. Peluang Usaha melalui Keterampilan Merajut bagi Anggota PKK RW-05 Kelurahan Lembah Sari Kecamatan Rumbai Pesisir Pekanbaru. Repository Unri.

Kotler, P. 2000. Prinsip - Prinsip Pemasaran Manajemen, Jakarta : Prenhalindo.

Kusumadewi, A. N., \& Fitriani, H. N. 2020. Implementasi Jiwa Wirausaha dan Pemanfaatan Media Sosial Terhadap Minat Berwirausaha Pada Mahasiswi Purwakarta. E-Qien Jurnal Ekonomi dan Bisnis Vo. 7 No 2.

Nastain, M. 2017. Branding dan eksistensi produk (kajian teoritik konsep branding dan tantangan eksistensi produk ). Vol 5(1):16

Pendit, P. L. 2003. Penelitian IImu Perpustakaan dan Informasi: suatu pengantar diskusi epistemologi dan metodologi. Jurusan IImu Perpustakaan-Fakultas Sastra, Universitas Indonesia (JIP-FSUI).

Rakhmawati, D., Ismah, \& Lestari , F. W. 2020. Sosialisasi Bahaya Kecanduan Gadget. Journal of Community Sevices Vol. 1 No 3.

Sari, R. 2016. Pemberdayaan Masyarakat Melalui Pengembangan. Jurnal Al-Bayan, 53-64. 